NOTA

235-249

\title{
EL SER HUMANO ANTE LA SOLEDAD MODERNA EN LA POESÍA DE MANUEL ALTOLAGUIRRE
}

Human being faced with contemporary solitude in Manuel Altolaguirre's poetry

\author{
Jorge González del Pozo* \\ Todo poeta verdadero al darnos su poesía \\ nos da también su propia clave \\ (López Castro, 269)
}

Manuel Altolaguirre (1905-1959), malagueño, hombre de familia, poeta, editor y en sus últimos años cineasta, termina recalando en Cuba y México, debido a la huida de la España franquista y el exilio. Este autor, en constante relación con la cultura, inquieto, sensible y de gran humanidad, ha sido recompensado por su trabajo poético en el último cuarto del siglo XX y a principios del siglo XXI. La relevancia que le fue negada tanto en vida, como póstumamente, ha sido recobrada al incluírsele en la llamada Generación del 27. Relegándolo a un papel secundario en el panorama cultural de su momento y con el agravante de su salida del país, se desperdició uno de los poetas más profundos de la época. Este aislamiento, junto con un constante nexo humano hacia su entorno personal y la permanente implicación de su vida en sus composiciones, dan un cariz realista a su obra, que no pierde el esteticismo y el romanticismo clave en el lirismo del momento.

Este análisis de la obra poética de Altolaguirre hace especial hincapié en sus imágenes y metáforas de corte humano, que se apartan de las corrientes vanguardistas y puramente esteticistas que se producían en las primeras décadas del siglo $\mathrm{XX}^{1}$. La producción de Altolaguirre durante la Guerra Civil Española permitirá descubrir una obra cargada de vida y conectada plenamente a la situación y condición humana de la población común. Este trabajo desvela el corte realista y comprometido con la sociedad de su poesía; de manera específica, la preocupación central de su obra por las personas del mundo moderno y manifiesta cómo sus inquietudes y reflexiones sobre el individuo se reflejan en su lírica. Finalmente, este estudio explora cómo el

\footnotetext{
${ }^{1}$ Díaz Fernández despliega la ideología acerca de su concepción del arte en su ensayo El nuevo romanticismo, su sentido de lo humano está muy presente en sus teorizaciones, así Ramón Ayéndez Alder explica en su artículo García Lorca, Díaz Fernández y el compromiso social del artista: "Según Díaz Fernández la experiencia de la guerra y el pesimismo subsiguiente habían dado paso a un apetito voraz de vitalismo y a una euforia física, vinculada al deporte y al placer fácil, que habían contribuido a que se perdiese el contacto con lo humano" (Ayéndez, 69). Esta pérdida es, para Díaz Fernández, una lacra en la sociedad a raíz de este concepto, sugiere una vuelta a los valores cívicos que se preocupan por el ser humano y por su situación, promoviendo una actuación consecuente en el arte: "El nuevo enfoque literario recibe el nombre de realismo social" (67).
} 
autor, con su poesía, busca despertar al ser humano contemporáneo y hacerle pensar en el verdadero sentido de su existencia, mediante la concienciación y un alegato metafísico con un anclaje en la vida crucial para desarrollarse como ciudadano, trazando un puente con el contexto actual que no dista mucho de la tensión y dudas de la situación contemporánea.

La problemática vital acuciante en la que se ve inmerso Altolaguirre se veía reflejada en el panorama artístico del momento ${ }^{2}$. La dicotomía en la que se desenvuelven las personas del momento les obliga bien a decidir entre claudicar y seguir la corriente capitalista, o bien, a reflexionar y ser conscientes de la situación de alienación del ser humano moderno y actuar a contracorriente en consecuencia:

Para el hombre moderno, sólo caben dos posibles actitudes: sucumbir al culto de lo material, vivir dominado por la tiranía de los números, del tiempo que es oro, y bajo la rutina conformista que imponen los valores de masa, o librarse y entregarse de nuevo a la vida, recobrando la perspectiva independiente que le permitirá cumplir de nuevo su papel creador frente a la realidad (Crispin, Quest, 109).

Las dos corrientes radicalmente opuestas que tenían lugar en la España de primeros de siglo, tienden a desligarse y separarse conceptualmente. El paralelismo entre las dos corrientes literarias, vanguardias y Generación del 27, crea una actitud ante la poesía muy contradictoria. Las vanguardias se perfilarán ante la composición lírica luchando por la separación del arte institucional y una idea de la poesía como expresión personal al margen de tendencias y experiencias (Díez de Revenga, 39). Por el contrario, los paradigmas de la Generación del 27 buscan un arte elitista, privilegiado y alejado de la realidad (Ortega y Gasset, 63) ${ }^{3}$. Estas bases se apoyan en la idea del distanciamiento del arte de todo atisbo de realidad que proponía la vanguardia desplegando una poesía pura desconectada de la cotidianeidad, y están reflejadas tanto en la creación artística del momento, como en la manifestación que aquí se describe, quedando claro que lo que pretende ante todo la poesía de vanguardia es superar el simbolismo y acercarse a las preocupaciones del ser humano moderno (Díez de Revenga, 14). Altolaguirre se decanta por la humanidad y por la

\footnotetext{
${ }^{2}$ Altolaguirre, desde muy joven, tuvo conexión con la creación literaria, ya que su padre fue un escritor de reputación en Málaga y vivió durante buena parte de su juventud en una calle nombrada en honor a su padre que murió cuando el poeta era niño (Bush, 137). Esta imagen constante y cotidiana de su padre como escritor, a la vez que la posible idealización del padre debido a esa pérdida temprana, pudieron haber contribuido a su concentración en el mundo literario.

${ }^{3}$ La muerte de la madre de este poeta en septiembre de 1926 será un pensamiento que no podrá sacar de la mente Altolaguirre durante toda su vida, esto es algo que se puede ver representado en buena parte de la composición lírica de este poeta: "La idea de la muerte, fundamental dentro de su obra poética, no le abandonará ya nunca" (Smerdou, 10). Ver Margarita Smerdou Altolaguirre para una mayor profundización en la obra de Altolaguirre por medio de su biografía.
} 
implicación con las problemáticas existenciales, tanto banales como más trascendentales, abandonando la tendencia general conformista ${ }^{4}$.

Por otro lado, la corriente paralela que tenía lugar era la que seguían los poetas de la Generación del $27^{5}$. Estos creadores se definen muy claramente de manera contraria a los autores vanguardistas preocupados exclusivamente por la estética y liderados por José Ortega y Gasset (González, 24). La búsqueda de la humanidad en el arte y la identificación del lector con la composición era algo que José Díaz Fernández proponía rotundamente en su obra El nuevo romanticismo: "Es natural que el nuevo arte se manifieste como centro y resumen de esa duda tan propia del hombre contemporáneo" (137-38). Asimismo, aseveraba que el producto final conseguiría su práctico objetivo que consistía en generar obras no solo basadas en una estética atractiva y refinada, sino también anclada en la expresión de las cuitas del ser humano del momento, ensalzando la forma de la poesía pero centrándose, de manera especial, en el contenido que conecta con el resto de la sociedad.

El gran romántico que aflora en Altolaguirre es una buena muestra de esas ideas que Díaz Fernández expuso y que flotaban en la concepción artística de ese

\footnotetext{
${ }^{4}$ La primera época de la revista Litoral surge bajo la dirección de Emilio Prados y Altolaguirre conjuntamente, en Málaga. Esta primera época solo dura dos años, 1926 y 1927, y se produce en los talleres de la Imprenta Sur. En su segunda época se une a la dirección José María Hinojosa y se publica a partir de 1929. Sufre un parón por la Guerra Civil y el exilio forzoso de sus directores, se reanuda su publicación en México en 1944, en los talleres de la Gráfica Panameña. Actualmente se ha reeditado gracias a la labor que José María Amado realizó en Torremolinos, volviendo a publicar viejos números y obras de estos autores (Mesa Toré, 75-76). Poesía surge bajo la dirección en solitario de Manuel Altolaguirre, durante los años 1930-1931. Altolaguirre publica esta revista desde su tierra natal en Limonar Alto, Málaga, utilizando una imprenta portátil, que más adelante trasladará a París donde continuará con la publicación de esta revista. Póstumamente ha sido reeditada por la editorial Turner en Madrid, en 1979 con preliminar de J. M. Rozas. Al igual que han surgido reediciones en 1986, publicadas por la Diputación de Badajoz, con prólogo de Jorge Guillén (Mesa Toré, 76). 1616 English and Spanish Poetry aparece bajo la dirección conjunta de Concha Méndez y Manuel Altolaguirre, que aportan, desde Londres, una revista con poemas y traducciones de autores ingleses y españoles. Posteriormente surge 1616, como edición facsímil con introducción de J. A. Muñoz Rojas y prólogo de Smerdou Altolaguirre en 1981, en la editorial Turner en Madrid (Mesa Toré, 77).

${ }^{5}$ Siguiendo la tesis de Irene Chico-Wyatt, en la que analiza en profundidad la obra de este poeta, se descubre la evolución que Altolaguirre hizo respecto del cine, ya que comienza pensando que "el autor es consciente de los nuevos caminos que el cine ofrece al mundo" (244). Y ciertamente es así para Altolaguirre en sus primeros acercamientos al cine: "Esta representación de lo indecible, es un arte poético, que puede producir las más hondas y perdurables emociones" (143). Desarrollando su faceta de literato en la composición de guiones cinematográficos y posteriormente lanzándose al mundo de la dirección, se siente cómodo y puede desplegar toda su capacidad creativa: "un cine sin imágenes, pero con voces tan expresivas, que sobre la pantalla se adivinan, hasta cobrar relieve los personajes" (154). No obstante, al final de su carrera se ve obligado a hacer cine por dinero, sin mayores miras artísticas, lo que se ve reflejado en su opinión posterior acerca del cine: "En el estudio de cine se menosprecia al escritor, tergiversando caprichosamente su script, se hacen pedazos las composiciones del músico, y de los actores más vale no hablar" (171). Estos comentarios critican el poder de la industria y la mecanización que tanto repudiaba Altolaguirre y que estaba representada por esos valores vanguardistas. Véase Manuel Altolaguirre: Ensayo bibliográfico, pp. 57-59.
} 
período ${ }^{6}$. Así, Altolaguirre mismo asegura: "la poesía moderna, que sobre la realidad primitiva, sobre el pensamiento clásico, sobre la pasión romántica, coloca la involuntaria y misteriosa intimidad de los sueños, poesía en la que el poeta revela su verdadera vida, la secreta complejidad de su entrañable naturaleza..." (En el campo, 272). Esta afiliación de pensamientos que se generaba entre los autores y la divergencia que procuraban con los artistas de la vanguardia se produce manifiestamente en su tratamiento de los recursos estéticos, particularmente en el uso de imágenes y metáforas. Altolaguirre intentaba alejarse del concepto de metáfora de Ortega y Gasset mediante la que el ser humano logra la evasión de la realidad; así, resumiendo su obra y su planteamiento: "la metáfora es el más radical instrumento de deshumanización" (48). Esta separación de la realidad es aclarada por Carmen Chust Jaurrieta en el artículo que disecciona detenidamente el concepto de metáfora de Ortega y Gasset, explicando cómo la no identidad afirmada por la metáfora en términos de objetividad desaparece (62). Autores como Guillermo de Torre explican mejor desde la distancia temporal la finalidad artística de la vanguardia y lo que representaba Ortega y Gasset: “... los [artistas] llevan a poner en el mismo nivel todos los elementos, rebasando las tímidas metas de las comparaciones conocidas" (De Torre, 295). De esta forma, la evolución artística hace converger los derroteros formales de las vanguardias con las temáticas realistas que despliega la obra de Altolaguirre?

El poeta seguirá las pautas y preceptos desarrollados por Díaz Fernández, dejando de lado estas diatribas modernistas. Así, Altolaguirre abogará por unas imágenes muy alejadas de las vanguardistas. El creacionismo y su imaginería son centrales en la obra de este poeta y se erigen como características que lo diferencian del resto de compañeros de generación (Crispin, Metáfora, 107). Altolaguirre llega a concebir tropos muy cercanos a los promulgados por Díaz Fernández y parte de la premisa de que la metáfora es una creación popular, un elemento que reside en la boca del pueblo (Crispin, La metáfora, 69), haciendo de la metáfora la principal herramienta para la traslación de la preocupación del ser humano desde la sociedad hasta la alta

\footnotetext{
${ }^{6}$ Ortega y Gasset (1883-1955) influyó de manera importante en el panorama cultural español del momento, posicionado primeramente a favor de las vanguardias y el arte elitista, como hacía constar en su ensayo La deshumanización del arte, se separaba totalmente de la realidad vital del artista: “...nueva sensibilidad está dominada por un asco a lo humano en el arte, muy semejante al que siempre ha tenido el hombre selecto a las figuras de cera" (42). Estos conceptos sobre el arte también se ven reflejados en la forma que Ortega desarrolla a la hora de componer, o cuando teoriza sobre los ideales estéticos del arte: "Para Ortega la metáfora evita la realidad, hace ocultación de las cosas... pero al suplantar una cosa por otra no pretende tanto alcanzar esta como evitar aquella" (Chust, 72).

${ }^{7}$ La problemática para definir la Generación del 27 se viene produciendo incluso desde que los integrantes de la misma estaban en pleno proceso activo: "no es fácil delimitar con exactitud las fronteras teóricas que individualizan a los poetas del 27 frente a los otros grupos" (González, 11). Asimismo, se produce la dualidad vanguardias-Generación del 27, aunque dependiendo de los autores se muestran las relaciones entre estos dos movimientos de una u otra manera: "Pero con la Generación de 1927 se inicia la segunda fase, de madurez, del experimento vanguardista" (Crispin, Metáfora, 107).
} 
cultura como es la poesía. Este poeta se asienta como un creador profundo, que intenta analizar la situación interior y exterior del ser humano y pretende trascender lo estrictamente estético y dar un paso más, llegando a contenidos más elevados en la vida cotidiana y mostrando las implicaciones que se producen en el arte. De este modo, Altolaguirre mismo expresa en sus ensayos su teoría artística: "Mientras pretenden imponerse por la novedad, no estaremos seguros de sus valores trascendentes. Sobre todo en el arte y en la literatura, en donde tantas horribles apariencias están condenadas al infierno" (Valender, 162). Es decir, la mayor preocupación del poeta es la conexión con los valores humanos y con los valores vitales, desprendiéndose de las tendencias de la moda artística y enfocándose principalmente en la sociedad.

La recuperación de Altolaguirre para el canon se perfila como un rescate importante para la poesía española del siglo XX. No es posible olvidar las aportaciones de James Valender a la crítica sobre este autor malagueño, y en especial la compilación de sus obras, tanto poéticas como de otros géneros. En esta dirección se pronuncia Valender: "Si Altolaguirre sigue siendo uno de los poetas menos estudiados de su generación, esto se debe en gran medida al hecho de que los lectores no han tenido acceso sino a una parte relativamente pequeña de su obra" (Valender, 7). La aproximación que la crítica ha hecho a este autor ha ido cambiando a lo largo del siglo pasado y siguiendo las ideas que los estudiosos españoles llegan a exponer en cuanto a la obra y a la figura de Altolaguirre ${ }^{8}$.

Este autor ha sido considerado recientemente como uno de los poetas vitalistas más cercanos al pueblo y más representativos de su tiempo: “....era entonces la juventud misma, la alegre y dorada inconsciencia de vivir" (Cano, La poesía, 14). El artista consigue una fusión entre la realidad a la que está expuesto y la visión íntima o apreciación personal que posee. De esta forma, su obra se comprende más claramente desde una óptica que expone la pasión por los distintos lenguajes artísticos con los que el ser humano expresa y da sentido tanto a una realidad común como a su propia singularidad (Mesa Toré, 10). La carga social de su poesía dota de un sentido general a su composición que le confiere gran balance entre el yo poético y el mundo exterior. En su colección de poemas publicados en México, Poesías completas, se hace patente esta mezcla, la que el propio autor establece como modo de enfrentarse a la obra y a la vida: "La poesía, ya sea exterior o profunda, es mi principal fuente de conocimiento. Me

\footnotetext{
${ }^{8}$ La crítica ha ido modificando su opinión sobre este poeta que, acertada aunque tardíamente, le ha introducido en el canon. Caso curioso es el de la antología que Joaquín González Muela y Juan Manuel Rozas editan, en su primera edición de 1966 no se estudia, ni siquiera se nombra a Altolaguirre, en la segunda edición de 1974, aparece nombrado como se puede apreciar en la cita de esta misma página, pero Altolaguirre no es objeto de estudio. En cambio en la tercera edición de 1986 figura como uno de los poetas que se tratan y una selección de sus composiciones aparece en la antología, al mismo nivel que cualquier otro de los autores de renombre ya consagrados de la Generación del 27. No deja de sorprender la falta de inclusión de Altolaguirre en el canon literario anterior, incluso cuando uno de esos poetas de renombre opinaba de esta forma sobre Altolaguirre: "Poeta mayor como lo considera Cernuda que tan parco fue en elogios para sus coetáneos" (Romojaro, 449).
} 
enseña el mundo y en ella aprendo a conocerme a mí mismo" (Poesías completas, 11), como se puede comprobar en declaraciones del propio Altolaguirre para esa compilación.

La producción lírica de este autor hasta la Guerra Civil Española (1936-1939) es amplia y generosa, siendo los principales temas que este poeta aborda durante el período de composición la naturaleza, el amor o la soledad. En resumen, trata la problemática que rodea al ser humano contemporáneo con una obra que muestra la preocupación y la conciencia hacia su sociedad. Una de las estudiosas que más han profundizado en este aspecto es María Luisa Álvarez Harvey en su análisis de la poesía de Altolaguirre Cielo y tierra en la poesía lírica de Manuel Altolaguirre. En el sentido tradicional y cristiano de la dicotomía cielo y tierra, las dos abstracciones, espiritu y alma, aluden a la sustancia espiritual e inmortal que, junto con el campo humano, constituyen la esencia del hombre; el cuerpo o la carne, a su vez, no ya abstracciones, sino nombres aplicados a la materia orgánica del hombre, se asocian con la pasión y el instinto (Álvarez Harvey, 3). La lucha que su poesía mantiene en el interior se basa en la propia exposición del conflicto entre cuerpo y espíritu, de forma que lo físico se muestra entrelazado con lo psicológico, irremediablemente.

La primera obra poética que produce Altolaguirre, Las islas invitadas y otros poemas (1926), utiliza como punto de apoyo las directrices que, para el estudio de la lírica de este autor, propone Álvarez Harvey: “...colorida y pintoresca, pudiendo apreciarse en ella, de inmediato, la tendencia del autor por describir con exquisitas pinceladas metafóricas la naturaleza que lo rodea....'(7). Así, su poema Negras cabras, desarrolla el tema de la naturaleza en unión con las preocupaciones del ser humano, viéndose de esta forma la primacía de la vida misma que Altolaguirre expone:

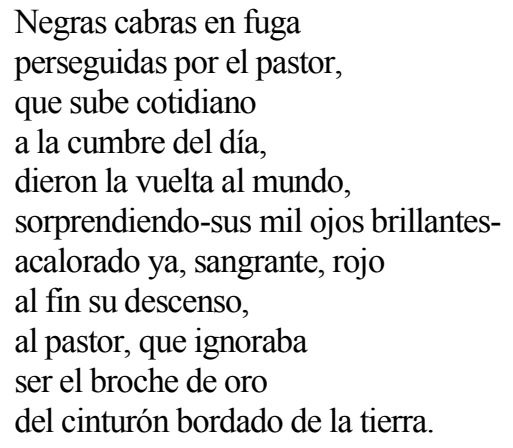

A pesar de las múltiples lecturas que se pueden hacer de estos versos, la interpretación de las metáforas aludidas anteriormente se desarrollan en este artículo bajo la preocupación de la sociedad del momento; las "negras cabras" son las propias inquietudes del "pastor", que se lee aquí como el ser humano coetáneo al autor. Al igual que los pastores, la voz lírica tiene que reunir su rebaño de ideas y no dejarlas escapar; las cabras, o preocupaciones, "dan la vuelta al mundo", es decir, una actividad o reflexión que ocurre en todos los lugares al común de las personas. El 
final del día, o cómo Altolaguirre lo describe, "el descenso", sería la reflexión que la gente común expone partiendo de las angustias humanas. La doble metáfora final: "...ser el broche de oro/ del cinturón bordado de la tierra". Implica que el ser humano "broche" está por encima del resto de cuestiones e ideologías y este broche permite al "cinturón" cohesionar a la sociedad. Este ser humano, además de su función central y motora para el colectivo, adorna como colofón, a modo de "bordado", la preocupación que denuncia. Es el colofón, el final grandioso que llena de vitalismo y esperanza al receptor o receptora de la obra que, a través de estos versos, puede contemplar escenas que van de la represión a la liberación y del aniquilamiento a un triunfante renacer (Cate-Arries, 14). La lucha que Altolaguirre despliega en sus obras se debate ante la opresión y busca con un optimismo tenaz la liberación por medio de la conciencia, la reflexión y la superación personal, promoviendo, con imágenes que buscan al ciudadano activo y comprometido, el resurgiminento de una masa social tanto dinámica como responsable con su entorno.

Siguiendo con esta composición y entrando más en profundidad en la obra de este autor, se aprecia en su poema "Hombres inmóviles", cómo se muestra otro de los intereses y desvelos que el poeta desarrollaba en su obra, el predominio de lo estético que imperaba en la época:

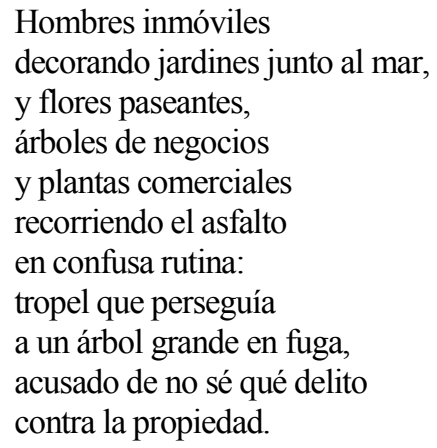

En esta creación se traban las desavenencias entre el arte que Altolaguirre desenvuelve y el arte paralelo que se generaba desde las corrientes vanguardistas: "El poeta, en su teoría especular, no se decide por qué es lo real, el lector no llega a saber lo que realmente lo es para el sujeto poético" (Romojaro, 431). Es decir, la dualidad artística que se producía en la época provoca la aparición de composiciones controvertidas, como es este caso; se muestra la voz lírica claramente opuesta al esteticismo puro que flotaba en el momento. Así los "hombres inmóviles" se encuentran estáticos, como meros adornos de suma belleza, los hombres trabajando, se ven sumidos en una rueda de progreso, mecanización y modernidad "recorriendo el asfalto/ en confusa rutina". Con los últimos versos, el poeta expresa su rechazo hacia la modernidad en que se basan las vanguardias, así como la animadversión al ver que poco a poco estas vanguardias se convierten en los elementos que rigen la vida diaria de la gente común. En estos versos expone el conflicto que generan los valores vanguardistas, mediante un 
caso muy particular "acusado de no se qué delito/ contra la propiedad", con lo que consigue la ridiculización a la que lleva una vida marcada por el avance científico y tecnológico; cuestionando el verdadero objetivo de la vida, mucho más cercano al beneficio que a la evolución de los valores humanos (Marx, 83). La crítica de estas composiciones hacia la distribución de la modernidad reside en el distanciamiento de una concepción de la sociedad en la que el ser humano es el centro y en el rechazo a la deshumanización que propone el avance capitalista de la época.

En Ejemplo (1927), los intereses del creador por la naturaleza han disminuido, la poesía se ha hecho más profunda, menos colorida, más íntima y reflexiva (Álvarez Harvey, 8). El poeta continúa con su análisis de las divagaciones del ser humano común en cuanto a los desasosiegos cotidianos. El poema Círculos de soledad propone una imagen de la vida moderna, dibuja una impresión personal acerca de la espera de una persona por otra, que se produce en cualquier punto de una ciudad. Se aprecia en estos versos la evolución en su introspección del hombre moderno, que tanto preocupa al artista y con la que tan identificado se siente ${ }^{9}$ :

Círculos de soledad
dibujados por mi espera.
Gritando sobre mis pies,
impaciente, arrastro y doblo
las puntas de mis miradas
sobre lo inútil perpetuo.
Sendero abrirá, llegando
a mi centro permanente;
radio de circunferencia,
minutero de reloj
señalando sus huellas.
Y quedará en mí o se irá
marcando nuevo camino
perpendicular al otro,
en ángulo al de llegada
gráfico cuarto de hora.
Impaciente espera larga.
Entre el horizonte ciñe
la estatua de mi ansiedad:
faro en un islote perdido,
monumento a la inquietud
en una plaza redonda.

\footnotetext{
${ }^{9}$ Altolaguirre desvela en muchas ocasiones su simpatía hacia el común de los seres humanos modernos, por medio de generalizaciones y de la inclusión dentro de esa masa de sí mismo. Así, por medio de la aproximación psicoanalítica que esta analista hace de la obra de Altolaguirre, ofrece la posibilidad de interpretar la obra del poeta no como una identificación con el individuo medio, sino como una separación de la propia personalidad del poeta que solo es capaz de exteriorizar a través de la obra de arte.
} 
El aburrimiento, junto con el paisaje de ciudad que el personaje del poema dibuja, contribuye a la monotonía de la urbe que pretende reflejar así Altolaguirre. La alusión al tiempo, que comienza a erigirse como mandatario principal en el momento de composición de la obra, es otro elemento de denuncia de la falta de humanidad que la vida moderna propicia. Altolaguirre deja ver esa sensibilidad superior que ostentan los artistas: "Solamente los poetas viven y se hacen viejos e imperecederos concediendo esta vida e inmortalidad a quienes quieren" (Valender, 266). Dentro de esa gran masa de personalidades que se conforman con la espera a la que le somete la sociedad, surge la figura contestataria, reflejada en la voz poética. Este "faro en islote perdido" se forma como el ser humano diferente que se cuestiona la dificil situación moral por la que atraviesa la humanidad de finales de la segunda década de los veinte. La metáfora del "islote" es la ejemplificación más clara donde se ve la necesidad de la poética de Altolaguirre de aferrarse a la realidad para intentar dar justificación a su existencia.

En la obra Ejemplo, descubre este poeta otra faceta dentro del progreso que implica el intento de resolver las dudas emergentes de una sociedad, que se sustenta y avanza a costa del olvido deliberado de los valores humanos y personales. La composición "Dominio" busca la enunciación de la lucha interna constante en el ser humano moderno, así como quiere aclarar los intentos por solventar las dudas que asaltan al sujeto y que se encuentran en la vorágine del mundo avanzado:

Desnudo campo terso
en el que se expansiona
elástica y segura
la voluntad del hombre.
Tensión firme del músculo
sometido al mandato
prudente del instinto.
Apártase, esquivando
con esbeltez, desdichas.
¡Que se pegue el toro
su testuz de piel áspera
contra las enguantadas
paredes del crepúsculo!
Vencer, poder saltar
sin vértigo barrancos;
arrebatar distancias
con el pecho por proa.
Firmeza en la soledad.
Juventud y dominio.

Por consiguiente, la obra expone aquí su ansia por aclarar y abrir su interpretación en busca de lo real sin descansar hasta descubrirlo desnudando la voz poética (López Castro, 243). Esta profundización en los intricados caminos del pensamiento, comienza 
por la afirmación del ser humano moderno como individuo con voluntad propia, "Desnudo campo terso/ en el que se expansiona," perfilándose así esta imagen como la libertad que en un principio propone la vida actual. Mediante el "instinto" confirma estas ideas de carácter personal del individuo, que intenta solucionar sus problemas para conseguir una vida mejor "esquivando... desdichas". La metáfora, que surge a colación "Que se golpee el toro," es otro de los ejemplos que Altolaguirre muestra, estableciendo la imagen del "toro" como el ser humano de arrojo y valentía, que se ve obligado a hacer su propia composición de lugar para poder comprender sus actos. La noche ("crepúsculo") y la soledad del pensamiento ("enguantadas paredes"), sirven de nexo con la vida real y cotidiana, mostrando así las complicaciones que se presentan para las personas de coraje que, solas ante los problemas, se enfrentan a la vida.

Su tercera composición poética, la obra Poesía de 1930, mantiene las temáticas que han sido ya clave para otras obras anteriores y analiza la situación del ser humano del momento. El poema La ventana sintetiza de manera muy concreta esa confluencia que explota Altolaguirre en su obra, resumiendo la problemática existencial, mediante la exploración de sus propios sentimientos e impresiones, bajo la estética y el tratamiento formal de su obra, que se encuentra en la encrucijada entre la modernidad y el contenido intimista:

La ventana separa

al mundo de los trenes, de los grandes vapores, a los hombres a pie, del mundo quieto de una alma sola. ¡Qué alegría ver los rosales y los vendedores! Al ruidoso paisaje de tráfico y de vida mi tristeza se asoma. Mi soledad consciente mira las hermosuras inútiles del mundo. Lo bello y el color es de las almas solas.

La principal reflexión que provoca este poema es la concepción de la soledad del ser humano actual en la sociedad moderna. El autor ofrece esta idea mediante la confrontación de los valores de antigüedad y modernidad. El uso de la metáfora "ventana", como el ser humano observador que se encuentra rodeado de contradicciones, como el progreso y la velocidad que suponen los "trenes", y lo tradicional y ralentizado que suponen los "vapores", son recursos que permiten a 
Altolaguirre asociar posteriormente conceptos como la naturaleza y la humanidad: "Que alegría/ ver los rosales y vendedores," que muestran su carácter protector para con los valores del corazón, en contraposición con la mecanización generalizada de la vida en las décadas de los 20 y los 30: “...una organización mecánica no permite el desarrollo espontáneo de las facultades humanas; el hombre no es en tal caso sino un engranaje del maquinismo, reducido a adaptarse a los movimientos automáticos del conjunto" (xxxiii). Las palabras de Karl Marx ilustran de manera clara la percepción que emana de la obra de Altolaguirre, en la aplicación de estas imágenes a la vida diaria de los seres humanos que cada vez se ven más desplazados de cualquier concepción existencialista y se encuentran más inmersos en la vorágine de la producción que anega los sentidos vitales. Más adelante expone claramente cuitas "Al ruidoso paisaje/ de tráfico y de vida/ mi tristeza se asoma," como el aislamiento del ser humano en su mundo privado, aunque esté circundado por un ajetreo constante. Por otro lado, expone también la desgracia en la que se ha caído, por el hecho de primar la estética pura y lo ornamental que no tiene ninguna utilidad ni fundamento vital: "las hermosuras/ inútiles del mundo".

Soledades juntas (1931) se enfoca en: “...la soledad y la tristeza, la muerte y el amor" (Álvarez Harvey, 11). El poema El mar constata estas inquietudes, que se caracterizan como obsesivas en la obra de Altolaguirre:

Nuestras vidas son los ríos
que van a dar al espejo
sin porvenir de la muerte.
Allá van nuestros recuerdos
mostrándonos lo que fuimos
y para siempre seremos,
cristal en que nuestras almas
revivirán lo vivido
en las prisiones del tiempo.
Estar lejos de la muerte
es no verse, es estar ciego,
con la memoria perdida,
nublado el entendimiento,
sin voluntad caminando,
volubles, desconociéndonos.

Estos versos plantean de manera directa el sentido de la vida sobre el que tanto reflexiona este autor mediante sus versos. Todo se verá reflejado al final de la vida, así lo expone el poema, utilizando el "mar" como metáfora que alude a un pozo sin fondo, a la inmensidad donde se pierde a los seres humanos, implicando cómo la sociedad se ha convertido en una masa asocial que elimina cualquier posibilidad de reconocimiento propio o ajeno en el otro y, por tanto, anula la oportunidad de liberación plena. Los versos comentan la experiencia vital y cómo las acciones marcan al individuo, con lo cual: "volverán al hombre y escucharán el rumor de su 
conciencia" (Díaz Fernández, 57), con un lenguaje sincero y claro. Al final de estos versos se aprecia a un ser resignado, aunque con un cierto espíritu interior presto a resurgir. Este individuo perdido que se muestra en el poema, se encuentra entre dos actitudes ante la vida que le pueden hacer diferir mucho su existencia. Por un lado, no asumir lo efímero de la vida, lo que no le permitirá realizarse $y$, por otro lado, asumir esa banalidad que le provocará la sensación de que su devenir es uno más dentro de la gran masa; es decir, la inutilidad de la vida y la constatación de ser una gota más en todo un "río" que va a parar al "mar".

La última obra que este estudio aborda analiza una de las creaciones inmediatamente anteriores a la Guerra Civil, La lenta libertad (1936) donde se aprecia "El tono de desilusión hacia el mundo que lo rodea" (Álvarez Harvey, 13) ${ }^{10}$. En el poema Polen se comprueba esa desazón que la composición desprende sobre el vacío del mundo moderno:

Somos el polen de la tierra,
oscura flor del firmamento,
el viento de la muerte nos arrastra
por los grises jardines de un ensueño.
Nuestra ausencia es tan solo
errático vagar entre luceros.
¿Qué nueva flor, enfrente de qué mundo,
nuevo narciso de tu pensamiento,
resucitada gloria ha de ofrecerte
ante la clara prisa de un espejo?
¿Qué forma soñarás para tu alma?
¿Cómo reconocerte si te encuentro?

El tono melancólico que muestra cuando expresa el paso de los seres humanos por la existencia y las preguntas retóricas que cierran esta composición, hacen de este breve poema una honda reflexión en cuanto a la identidad. Las metáforas que despliega, especialmente en estos versos, tienen un arraigo en la vida cotidiana; de esta forma, el "polen" alude a las personas como la esencia vital del mundo y, como tal esencia, los versos de Altolaguirre recuerdan que el ser humano debe prevalecer alejado de la mera producción capitalista y tomar el mando de su existencia (Marx, 227). También la creación representa la tristeza del engaño en el que vive inmersa la sociedad por medio de la metáfora "los grises jardines de un ensueño," donde la voz principal anuncia su enfado con la existencia que está viviendo y lo extrapola hasta otros individuos, mostrándose como un sentimiento de vida en "ausencia".

\footnotetext{
${ }^{10}$ Las creaciones de Manuel Altolaguirre durante la Guerra Civil y posteriormente a ella, son de un carácter completamente distinto. De esta forma Claude Le Bigot analiza en su artículo Manuel Altolaguirre o la circunstancia elevada: "El romance de guerra se agarra a la actualidad..." (171), manteniendo un nexo con su producción anterior que luego romperá para dar directrices moralistas por medio de una: "...lucha ideológica, el discurso que mantiene con su público es inevitablemente doctrinal..." (170).
} 
En definitiva, se descubre a lo largo de la poesía de Altolaguirre una mirada cercana y un apego a la vida misma y a la realidad circundante a los seres humanos, que no se quedaban en la superficialidad de la mera existencia banal y cotidiana que el quehacer diario deparaba, sino que mediante esta poesía personal de acuciantes temas contemporáneos se veían tocados por la sensibilidad visionaria de esta obra (Crispin, Metáfora, 109). De forma clarividente, se puede apreciar un autor que plantea los problemas que las personas de la edad moderna padecían. El artista tratado durante este estudio desarrolla una serie de implicaciones necesarias para cualquier creador: "El poeta que hace de su obra vida, que no vive, que entrega en sus versos su humanidad, soñada o cantada, que escucha o lee las vidas de los demás, que llora, exalta, condena, dice que sí, o que no desde el gris escondrijo..." (Valender, 263-64), tratando el grado en el que se llega a involucrar el autor y que le permite llegar a su público, así como hacerle sentirse identificado con sus composiciones. Esta actitud ante el arte y la composición artística, junto con la consideración que mantiene hacia su público, muestran la cercanía del poeta a los pensamientos de Díaz Fernández: "Saludemos al nuevo romanticismo del hombre y la máquina que harán un arte para la vida, no una vida para el arte" (58). Esta disociación que procura en su obra poética también se puede vislumbrar en su obra crítica: "Por mi parte aseguro que prefiero la espiritualidad de estas rememoraciones, que la material presencia de lo novedoso" (Valender, 162). Su simpatía por los temas que son materia diaria de reflexión del ser humano contemporáneo se muestra no sólo en el contenido de su obra, sino también en la disposición y el aporte de sus poemas como el complemento necesario para crear un balance entre el arte y la realidad.

De esta forma, una de las motivaciones centrales a lo largo de la composición lírica producida con anterioridad a la Guerra Civil por Altolaguirre, es la constante preocupación por el rumbo que las personas se marcaban y, cómo la sociedad, problemática y controvertida en una época caracterizada por el progreso, imbuía al ser humano a una inseguridad acuciante. La suscitación sobre el sentido de la vida que Altolaguirre proponía, no se alejaba para nada del pensamiento que el colectivo generaba, con lo que sugería una obra imbricada en las divagaciones de la mente humana $\mathrm{y}$, por consiguiente, planteaba a su audiencia la meditación acerca de parámetros vitales para la realización personal y para la comprensión de la existencia del ser humano. La dedicación y grado de compromiso con su sociedad de autores como Altolaguirre, lejos de estar obsoletas, se manifiestan más en vigencia que nunca y así lo demuestra la reciente inclusión de este artista en el canon literario español. La obra de Altolaguirre, hasta hace poco dejada a un lado, se acerca más a la perspectiva contemporánea en una visión actual que se muestra formalmente a caballo entre el creacionismo y la estética de la poesía pura, pero que a nivel de contenido se acerca más al enfoque en el grado de alienación del individuo, componente ínfimo de una sociedad que le relega a la categoría de engranaje, sin preocuparse por los sentimientos que forman la esencia de la vida. No está de más, pues, la revisión de la obra de este poeta del pueblo que se preocupa de lo mismo de lo que se preocupan sus 
coetáneos, especialmente en unos tiempos críticos, tanto ayer como hoy, en los que el bienestar individual pasa indiscutiblemente por el bienestar del colectivo.

The University of Michigan-Dearborn* Dept. of Language, Culture and Communication 4901 Evergreen Road, 3016 CB, Dearborn, MI, 48128 (U.S.A.) jorgegdp@umd.umich.edu

\section{OBRAS CITADAS}

Altolaguirre, Manuel. Poesías Completas, 1926-1959. México: Tezontle, 1960.

Álvarez Harvey, María Luisa. Cielo y tierra en la poesía lírica de Manuel Altolaguirre. Hattiesburg, MS: UP of Mississippi, 1972.

Ayéndez Alder, R. "García Lorca, Díaz Fernández y el compromiso social del artista". Crítica Hispánica. 10.1 (1988): 67-92.

Bush, Andrew. "Manuel Altolaguirre, The dialogue of poetry". Modern Language Studies. 15.4 (1985): 135-42.

_L La poesía de la Generación del 27. Madrid: Guadarrama, 1973.

Cate-Arries, Francie. "Manuel Altolaguirre through the looking glass: The art of selfreflection". Anales de la Literatura Española Contemporánea. 13.3 (1988): 209-38.

Chico-Wyatt, Irene. "Proceso intertextual en la obra literaria y cinematográfica de Manuel Altolaguirre". University of Kentucky, 2001.

Chust Jaurrieta, Carmen. "La metáfora en Ortega y Gasset". Boletín de la Real Academia Española 43 (1963): 57-150.

Crispin, John. "Metáfora y mito en la Generación de 1927: El caso de Pedro Salinas". Journal of Spanish Studies Twentieth Century 6 (1978): 107-23.

Quest for Wholeness: The Personality and Works of Manuel Altolaguirre. Valencia: Albatros Hispanófila, 1983.

De Torre, Guillermo. "Imagen y metáfora en la poesía de vanguardia". Cuadernos Hispanoamericanos: Revista Mensual de Cultura Hispánica 75 (1968): 272-95.

Díaz-Fernández, José. El nuevo romanticismo: polémica de arte, politica y literatura. Madrid: J. Esteban, 1985.

Díez de Revenga, Francisco Javier. Los poetas del 27, clásicos y modernos. Murcia: Ediciones Tres Fronteras, 2009.

González, Ángel (ed.). El grupo poético de 1927. Madrid: Taurus, 1976.

Le Bigot, Claude. "Manuel Altolaguirre o la circunstancia elevada". Analecta Malacitana: Revista de la Sección de Filología de la Facultad de Filosofia y Letras 11.1 (1988): 169-97.

López Castro, Armando. "Manuel Altolaguirre, poeta del universo interior" Boletin de la Biblioteca Menéndez Pelayo 70 (1994): 237-70. 
Marx, Karl. El capital. Estudio sobre el socialismo científico. Madrid: Ricardo Fé, 1887.

Mesa Toré, José A. Manuel Altolaguirre: Ensayo bibliográfico. Málaga: Centro Cultural de la Generación del 27, 1991.

Ortega y Gasset, José. La deshumanización del arte y otros ensayos estéticos. Madrid: Revista de Occidente, 1967.

Romojaro, Rosa. "La poesía de Manuel Altolaguirre: Poética de la dualidad" Revista de Literatura 53.116 (1996): 427-29.

Smerdou Altolaguirre, Margarita (ed.). Las islas invitadas. Madrid: Castalia, 1973.

Valender, James, (ed.). Manuel Altolaguirre: Obras Completas, I: El Caballo Griego, Crónicas y Artículos. Estudios Literarios. Reseñas de Libros. Notas Diversas. Madrid: Istmo, 1986. 